Original Article

\title{
Evaluation of sulfadimidine, amprolium and triquen to treat coccidiosis in wild pigeons
}

\author{
Avaliação da sulfadimidina, amprólio e triquenho no tratamento da coccidiose em \\ pombos selvagens de Lower Dir, Khyber Pakhtunkhwa, Paquistão
}

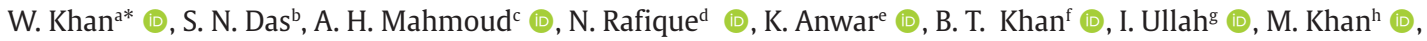 \\ S. Gula , R. Gula and O. B. Mohammed ${ }^{\text {c }}$ (i) \\ aUniversity of Malakand, Department of Zoology, Lower Dir, Khyber Pakhtunkhwa, Pakistan \\ 'Sindh University Jamshoro, Department of Zoology, Hyderabad, Pakistan \\ 'King Saud University, College of Science, Department Zoology, Riyadh, Saudi Arabia \\ dAbdul Wali Khan University, Department of Zoology, Mardan, Pakistan \\ eVeterinary Research and Diseases Investigation Center, Department of Livestock and Dairy Development, Balogram Swat, Khyber \\ Pakhtunkhwa, Pakistan \\ fUniversity of Buner, Department of Zoology, Buner, Pakistan \\ gUniversity of Agriculture Peshawar, Department of Veterinary and Animals Sciences, Peshawar, Pakistan \\ hUniversity of Peshawar, Department of Zoology, Peshawar, Pakistan
}

\begin{abstract}
Coccidiosis remains one of the major problems in poultry all over the world. Very limited data on anticoccidial drugs in wild pigeons is available. The current study was aimed to understand the comparative efficacy of sulfadimidine, amprolium and triquen in wild pigeons of Dir district, Pakistan suffering from coccidiosis. The faecal matter of wild pigeons were purchased from the local market for coccidian infection. Results revealed that $88.8 \%$ (16/18) were found infected with Eimeria spp. Three positive groups were treated with sulfadimidine $(0.2 \mathrm{mg} / \mathrm{L})$, amprolium $(25 \mathrm{mg} / \mathrm{L})$ and triquen. Sulfadimidine was most effective (45\%) followed by amprolium (44.6\%) while triquen $(24.0 \%)$ showed less effectiveness against coccidiosis in pigeons. Number of oocysts were 79,81 and 80 before treatment and 60, 44 and 44 after treatment with sulfadimidine, amprolium and triquen respectively. This study showed that sulphadimidine, amprolium and triquen could not significantly reduce the coccidiosis in pigeons. Further studies are required to clear the mechanism of anti-coccidial drugs in wild pigeons.
\end{abstract}

Keywords: wild pigeons, coccidiosis, prevalence, oocysts, anticoccidial drugs.

\begin{abstract}
Resumo
A coccidiose continua sendo um dos maiores problemas em aves de todo o mundo. Dados muito limitados sobre drogas anticoccidiais em pombos selvagens estão disponíveis. 0 presente estudo teve como objetivo compreender a eficácia comparativa da sulfadimidina, amprólio e triquenho em pombos selvagens do distrito de Dir, no Paquistão, que sofrem de coccidiose. A matéria fecal dos pombos selvagens foi comprada no mercado local para infecção por coccídios. Os resultados revelaram que 88,8\% (16/18) foram encontrados infectados com Eimeria spp. Três grupos positivos foram tratados com sulfadimidina $(0,2 \mathrm{mg} / \mathrm{L})$, amprólio $(25 \mathrm{mg} / \mathrm{L})$ e triquenho. A sulfadimidina foi mais eficaz (45\%), seguida pelo amprólio (44,6\%), enquanto o triquenho (24,0\%) apresentou menor efetividade contra a coccidiose em pombos. O número de oocistos foram 79, 81 e 80 antes do tratamento e 60, 44 e 44 após o tratamento com sulfadimidina, amprólio e triquenho, respectivamente. Este estudo mostrou que sulphadimidine, amprolium e triquen não poderiam reduzir significativamente a coccidiose em pombos. Mais estudos são necessários para limpar o mecanismo de drogas anticoccidiais em pombos selvagens.
\end{abstract}

Palavras-chave: pombos selvagens, coccidiose, prevalência, oocistos, drogas anticoccidianas.

\section{Introduction}

Coccidiosis is an intestinal sporozoic parasitic protozoan infection of birds and mammals. Nine species of the genus Eimeria, have been studied throughout the world, but only three are of economic importantance: Eimeria columbae,
E. columbarum and E. labbeana, which are characterized by varying degrees of virulence. The occurrence of these species was found in domestic pigeons (Columba livia domestica) and rock pigeons (Columba livia livia)

*e-mail: walikhan.pk@gmail.com

Received: August 25, 2020 - Accepted: September 2, 2020 
(Krautwald-Junghanns et al., 2009). E. labbeana, which lives in the small intestine of pigeons, causes, diarrhea, enteritis and even mortality of the infected birds. These coccidial organisms survive in the environment of the walls of oocysts. The infected birds excrete oocysts in their feces to provide a source of infection for other birds. The impacts of disease on animal agriculture include, lost revenues, costs of vaccination, prevention, eradication, decontamination and restocking. The life cycle of Eimeria is completed within seven days and multiplication begins when active oocysts are picked up by the birds and swallowed. After being swallowed coccidia inter into the intestinal lining and multiply several times and damage tissues. The incidence of coccidiosis in commercial poultry has increased due to higher stocking densities and intensive husbandry practices (Williams, 1999). It has been documented that it is the most consistently reported health problem in Poultry (Khan et al., 2006). Over three billion dollars are spent worldwide for the prevention of coccidiosis in poultry (Williams, 1999).

Epidemiological studies showed the economic importance of coccidiosis as a major parasitic disease of poultry in Nigeria (Chapman, 2008). Coccidiosis is a common and fatal disease in poultry including pigeons and estimated to be 2 billion dollars a year (Zhang and Zeng, 2005). Coccidiosis is a self-limiting disease, and its manifestation depends on the number of oocysts ingested and the immune status of the host.

About one fourth of world's meat supply is derived from poultry including pigeons and the proportion is increasing gradually in South Asian countries such as Sri-lanka, India, Bangladesh and Pakistan that represent about 22\% of world population (Prabakaran, 2003). Pakistan is deficient in the production of animal protein foods for its increasing human population, as demand of poultry products is so much higher as compared to their production (Abedullah et al., 2007). The limitations to increased poultry products are parasitic diseases of birds. Helminths and protozoan infections can frequently be a major problem causing morbidity and even mortality in the birds (Khan et al., 2018; Kamal et al., 2020). Keeping in view coccidiosis as the major health problem in wild birds, present study was conducted to detect the prevalence and control of coccidiosis in wild pigeons through different chemotherapeutic agents.

\section{Materials and Methods}

\subsection{Study area}

Present study was carried out in Lower Dir district, Khyber Pakhtunkhwa, Pakistan. Its geographical coordinates are $34^{\circ} 33^{\prime}$ 56" North, $71^{\circ} 55^{\prime}$ '52" East This area is characterized by heavy rain fall in winter and hot weather in summer. Temperature range from $12^{\circ} \mathrm{C}$ up to $40^{\circ} \mathrm{C}$.

\subsection{Ethical approval}

This study was approved by the ethical review committee of Department of Zoology, University of Malakand, Lower Dir, Pakistan.

\subsection{Data collection}

The pigeons about one year of age were collected from April 2016 to September 2016. Fresh faecal samples were collected in mini-plastic container and preserved in $10 \%$ formalin for coccidian infection screening.

\subsection{Diagnostic techniques}

\subsubsection{Direct smear examination}

About $1 \mathrm{~g}$ of feces was mixed with 20-25 ml of normal saline solution. The suspension was passed through a mesh and 1-3 drops of strained material were placed on clean glass slide and a thin layer of smear was made which was examined under the microscope detection of Eimeria sp. oocysts. Five slides from different parts of the same stool sample were examined. Samples found negative for Eimeria sp. oocysts were exposed to Sedimentation and Flotation techniques (Permine and Hansen, 1998).

For floatation about $1 \mathrm{~g}$ of fecal sample was suspended in $15 \mathrm{ml}$ water and strained through a cheese cloth. The suspension was allowed to settle for $10-15 \mathrm{~min}$ in the container. The sediment was mixed with saturated salt solution of $\mathrm{NaCl}$ in a centrifuge tube and shaken for $5 \mathrm{~min}$. The oocysts floated to the top surface which were picked by the cover slip.

For sedimentation technique one gram of feces was mixed with $10-15 \mathrm{ml}$ of tap water in a bottle and shanked it thoroughly. The suspension was passed through a filter. The strained fluid was poured in to a tube and again shacked for $5 \mathrm{~min}$. The supernatant was discarded and a drop of sediment was placed on glass slide and examined under low and high power of microscope for the presence of coccidian oocysts.

Three groups of pigeons were treated with sulfadimidine $(0.2 \mathrm{mg} / \mathrm{L})$ amprolium $(25 \mathrm{mg} / \mathrm{L})$ and triquen $(2.5 \mathrm{gm})$. Faecal samples collected were analyzed in the Laboratory. OPG count were performed by using McMaster Techniques described by Jarvie et al. (2005). The \% efficacies of the drugs (Trustfield, 2005) were measured by faecal oocysts per gram counts reduction test calculated from the arithmetic mean of the group OPG as per the formula given below: Efficacy of drug treatment (\%) = Mean pretreatment OPG-Mean-Post treatment OPG x 100/ Mean pre-treatment OPG.

\subsubsection{Statistical analysis}

The overall parasites found in pigeons were statistically analyzed by using a following Formula 1:

Prevalence Rate $=$ Total No. of pigeons infected $\times 100 /$

Total No. of pigeons examined

\section{Results}

A total of 18 pigeons were examined for the determination of parasitic infections. Out of the total pigeons examined 16 pigeons were found to be infected with coccidiosis caused by Eimeria sp. with overall prevalence of $88.8 \%$ ( $n=16 / 18$ ). The OPG values in faecal samples in different treatment groups are given in Table 1. 
Table 1. Comparative efficacy of three drugs against Eimeria sp. in 18 pigeons in Malakand region Groups.

\begin{tabular}{cccc}
\hline Group & NOPG Before treatment & NOPG After treatment & Drugs \\
\hline Group A & $8 \pm 2.74$ & $2.2 \pm 1.74$ & Sulphadimidin \\
Group B & $8.6 \pm 3.07$ & $2.2 \pm 1.614$ & Amprolium \\
Group C & $7.9 \pm 2.64$ & $2.76 \pm 2.22$ & Triquen \\
\hline
\end{tabular}

NOPG: number of Oocysts per gram.

Table 2. Oocyst reduction rate (ORR) against efficacy of drugs administered.

\begin{tabular}{ccccc}
\hline $\begin{array}{c}\text { No. of pigeons } \\
\text { positive for } \\
\text { coccidiosis in each } \\
\text { group }\end{array}$ & $\begin{array}{c}\text { Oocysts before } \\
\text { Treatment }\end{array}$ & $\begin{array}{c}\text { Oocysts after } \\
\text { Treatment }\end{array}$ & Oocyst reduction rate & Drugs \\
\hline 5 & 79 & 60 & $24.05 \%$ & Triquen \\
6 & 81 & 44 & $44.68 \%$ & Amprolium \\
5 & 80 & 44 & $45 \%$ & Sulphadimidine \\
\hline
\end{tabular}

For all the groups, the chi square statistic is not significant at $\mathrm{P}<0.05)$. The percent efficacies of different drugs against coccidiosis are shown in Table 2 . The efficacies of sulphadimidine, amprolium and triquen were $45 \%, 44.6 \%$, and $24.0 \%$ respectively.

\section{Discussion}

Present research focused on the prevalence of coccidiosis and efficacy of sulfadimidine, amprolium and triquen against coccidiosis in pigeon of the Lower Dir district, Pakistan. Current investigation reveals $88.8 \%$ ( $n=16 / 18$ ) prevalence rate. Our findings were comparable with the study conducted by others (Sari et al., 2008; Bobrek et al., 2012). According to Latif et al. (2016) the prevalence of coccidiosis infection was less in pigeons as compared to the present findings. The main factor behind this less prevalence of infection might be that the pigeons that are used by them are bred in poultry farms under proper hygienic conditions and appropriate vaccination after stipulated intervals against various infections administered while the pigeons used in present experiment were taken from the open environment in which therefore, the chances of parasitic infection are comparatively higher because they are inhabitant of open environment with microbial contamination which is manifested in the unhygienic feeding habits, because they are not subjected to vaccination and vice versa. Wild birds are reservoir of many parasitic diseases and play important role in contaminating the environmental agencies like water, soil, crops, fruits, vegetables etc and thus transfer the parasitic infections to the healthy birds through their plumage and fecal matter which are serious hazards for healthy birds.

Our study showed that sulphadimidine, amprolium and triquen could not inhibit the coccidiosis in pigeons. Our study is in conflict with the similar studies conducted by Avais et al. (2016) from Pakistan on the evolution of anticoccidioal drugs and have reported $95.4 \%$ and $98.1 \%$ efficacy of sulphadimidine and amprolium respectively, while in present experiment sulphadimidine was noted with highest percentage of oocyst reduction rate which is $45 \%$ followed by amprolium $44.68 \%$ while the least oocyst reduction rate was observed in triquen $24.05 \%$ respectively. Another study conducted by Abakar et al. (2005) from Sudan on the efficacy of sulphadimidine and amprolium against coccidiosis and reported $93.89 \%$ and $98.44 \%$ efficacy respectively. A study conducted by (Adewole, 2012) showing high efficacy of sulphadimidne and amprolium against coccidiosis.

In conclusions, Pakistan is deficient in the production of animal protein food, therefore, there was a need to determine the prevalence of coccidian infection in pigeons and its control through different anticoccidial drugs are needed.

\section{Acknowledgements}

The animal house keeper, of the University of Malakand, Pakistan, for the cooperation is acknowledged. The authors extend their appreciation to the researchers supporting project number (RSP-2020/94)King Saud University, Riyadh, Saudi Arabia.

\section{References}

ABAKAR, A.D., SERI, H.I., ISMAIL, A.A. and MUSA, H.H., 2005. Comparative efficacy of selected anticoccidial drugs in ambarorow sheep naturally infected with Enteric Coccidia in South Darfur, Sudan. The Sudan Journal of Veterinary Research (Pulawy), vol. 20, pp. 61-67.

ABEDULLAH, A., MAQBOOL, A. and BUKHSH, K., 2007. Issues and economics of poultry production: a case study of Faisalabad, Pakistan. Pakistan Veterinary Journal, vol. 27, no. 1, pp. 25-28.

ADEWOLE, S.O., 2012. The efficacy of drugs in the treatment of coccidiosis in chicken in selected poultries. Academic Research International, vol. 2, no. 1, pp. 20-24.

AVAIS, M., RASHID, G., IJAZ, M., KHAN, M.A., NASIR, A., JAHANZAIB, M.S., KHAN, J.A., HAMEED, S. and REICHEL, M.P., 2016. 
Evaluation of furazolidone, sulfadimidine and amprolium to treat coccidiosis in beetal goats under field conditions. Pakistan Journal of Pharmaceutical Sciences, vol. 29, no. 2, pp. 485-487. PMid:27087093.

BOBREK, K., GAWEŁ, A., PIASECKI, T., BOBUSIA, K. and MAZURKIEWICZ, M., 2012. Extensivness and intensity of invasion of intestinal parasites in flocks of racing pigeons in the south of Poland. Acta Scientiarum Polonorum. Medicina Veterinaria, vol. 11, no. 2, pp. 5-10.

CHAPMAN, H.P., 2008. Evaluation of the efficiency of anticoccidial drugs against Eimeria species in the fowl. International Journal for Parasitology, vol. 28, no. 7, pp. 1141-1144. http://dx.doi. org/10.1016/S0020-7519(98)00024-1. PMid:9724885.

JARVIE, B.D., TROTZ-WILLIAMS, L.A., MCKNIGHT, D.R., LESLIE, K.E., WALLACE, M.M., TODD, C.G., SHARPE, P.H. and PEREGRINE, A.S., 2005. Effect of halofuginone lactate on the occurrence of Cryptosporidium parvum and growth of neonatal dairy calves. Journal of Dairy Science, vol. 88, no. 5, pp. 1801-1806. http://dx.doi.org/10.3168/jds.S0022-0302(05)72854-X. PMid:15829673.

KAMAL, M., KHAN, W., NISA, N.U., YASMEEN, G., HASSAN, H.U. and IHSANULLAH, I., 2020. Acute raillietiniasis in domestic pigeon (Columba livia domestica). Advances in Animal and Veterinary Sciences, vol. 8, no. 11, pp. 1180-1183. http://dx.doi.org/10.17582/ journal.aavs/2020/8.11.1180.1183.

KHAN, M.Q., IRSHAD, H., ANJUM, R., JAHANGIR, M. and NASIR, U., 2006. Eimeriosis in poultry of Rawalpindi/Islamabad area. Pakistan Veterinary Journal, vol. 26, no. 2, pp. 85-87.

KHAN, W., GUL, S., GUL, M. and KAMAL, M., 2018. Prevalence of parasitic infestation in domestic pigeons at Malakand region, Khyber Pakhtunkhwa, Pakistan. International Journal of Biosciences, vol. 12, no. 4, pp. 1-7. http://dx.doi.org/10.12692/ijb/12.4.1-7.
KRAUTWALD-JUNGHANNS, M.E., ZEBISCH, R. and SCHMIDT, V., 2009. Relevance and treatment of coccidiosis in domestic pigeons (Columba livia forma domestica) with particular emphasis on toltrazuril. Journal of Avian Medicine and Surgery, vol. 23, no. 1, pp. 1-5. http://dx.doi.org/10.1647/2007-049R.1. PMid:19530399.

LATIF, A.A., FAZAL, S., MANZOOR, F., MAQBOOL, A., ASGHAR, S., WAJID, I. and ASHRAF, A., 2016. A comparative study on prevalence of coccidian parasites in broiler chicken (Gallus gallus domesticus), Japanese quail (Coturnix coturnix japonica) and wild pigeon (Columba livia). Pakistan Journal of Zoology, vol. 48, no. 1, pp. 295-297.

PERMINE, A. and HANSEN, J.W., 1998. Samples negative with direct smear examination subjected to Sedimentation and Flotation technique examination .... Science, vol. 129, pp. 267-268.

PRABAKARAN, R., 2003. Good practices in planning and management of integrated commercial poultry production in South Asia. Rome: FAO, no. 159.

SARI, B., KARATEPE, B., KARATEPE, M. and KARA, M., 2008. Parasites of domestic (Columba livia domestica) and wild (Columba livia livia) Pigeons in Nigde, Turkey. Bulletin- Veterinary Institute in Pulawy, vol. 52, no. 4, pp. 551-554.

TRUSTFIELD, M., 2005. Veterinary epidemiology. 3rd ed. London: Blackwell publishing Company.

WILLIAMS, R.B.A., 1999. Comparative study on prevalence of Coccidian Parasites in Broiler Chicken (Gallus gallus domesticus), Japanes Quail (Coturnix coturnix japonica) and Wild Pigeon (Columba livia). Pakistan Journal of Zoology, vol. 48, no. 1, pp. 295-297.

ZHANG, Z.M. and ZENG, M.H., 2005. Researches advance of drug resistance in chicken coccidia. Chinese Journal of Veterinary Parasitology, vol. 2, pp. 29-36. 


\section{BRAZILIAN JoURnAL OF BIOLOGY}

Erratum

\section{ERRATUM}

In the article "Evaluation of sulfadimidine, amprolium and triquen to treat coccidiosis in wild pigeons", DOI: https://doi.org/10.1590/1519-6984.238673, published in Braz. J. Biol. vol.82 São Carlos 2022 Epub March 12, 2021, in the section:

Where it reads:

Notes and Comments

It should be read:

Original Article 